NBER WORKING PAPER SERIES

\title{
A POLLUTION THEORY OF DISCRIMINATION: MALE AND FEMALE DIFFERENCES IN OCCUPATIONS AND EARNINGS
}

\author{
Claudia Goldin
}

Working Paper 8985

http://www.nber.org/papers/w8985

\author{
NATIONAL BUREAU OF ECONOMIC RESEARCH \\ 1050 Massachusetts Avenue \\ Cambridge, MA 02138 \\ June 2002
}

At its inception, about a decade ago, this paper benefited from the comments of seminar participants at Columbia University, Indiana University, University of Michigan, and Princeton University and from suggestions made by Becky Blank, Nancy Folbre, Alan Krueger, Peter Kuhn, and Gavin Wright. In its more recent incarnation, it has benefited from comments by Francine Blau and Larry Katz. This paper was an integral part of my Marshall Lectures, University of Cambridge, April 30 and May 1, 2002. The views expressed herein are those of the author and not necessarily those of the National Bureau of Economic Research.

(C) 2002 by Claudia Goldin. All rights reserved. Short sections of text, not to exceed two paragraphs, may be quoted without explicit permission provided that full credit, including (C) notice, is given to the source. 
A Pollution Theory of Discrimination:

Male and Female Differences in Occupations and Earnings

Claudia Goldin

NBER Working Paper No. 8985

June 2002

JEL No. J7, N3, J2

\begin{abstract}
Occupations are segregated by sex today, but were far more segregated in the early to midtwentieth century when married women began to enter the labor force in large numbers. It is difficult to rationalize sex segregation and "wage discrimination" on the basis of men's taste for distance from women in the same way differences between other groups in work and housing have been explained. Rather, this paper constructs a "pollution" theory model of discrimination in which new female hires may reduce the prestige of a previously all-male occupation. The predictions of the model concern the range of segregated and integrated occupations with respect to a productivity characteristic and how occupational segregation changes as the characteristic distributions become more similar by sex. The historical record reveals numerous cases of the model's predictions. Occupations that were more segregated by sex, for both men and women, contained individuals with higher levels of the productivity characteristic. "Credentialization," the shattering of old stereotypes, and information about individual women's productivities can help expunge "pollution."
\end{abstract}

Claudia Goldin

Department of Economics

Harvard University

Cambridge, MA 02138

and NBER

cgoldin@harvard.edu 
"It is not difficult to see how pollution beliefs can be used in a dialogue of claims and counter-claims to status."

Mary Douglas, Purity and Danger (1966, p. 3)

Women work in occupations that are different from those of men and get paid less for apparently the same personal and job characteristics. ${ }^{1}$ These differences have, in part, been attributed to economic discrimination that some have attributed to "tastes." The most cited treatise on the subject posits that some persons desire to work and live apart from others and would require a premium to interact with them. ${ }^{2}$

Yet men and women seem to get along under a wide variety of circumstances. Men often have wives, sometimes daughters and sisters, and by necessity mothers. One cannot attribute to most men a desire for distance from women the same way one might interpret current or past discrimination between other groups, such as blacks and whites, Catholics and Protestants, Arabs and Israelis. One might, however, attribute to men a desire for distance from women to protect their status as members of an occupational group.

The model developed here treats discrimination as the consequence of a desire by men to maintain their occupational status or prestige, distinct from the desire to maintain their earnings. (The reason for focusing on prestige rather than wages is later defended.) Prestige, in this setting, is conferred by some portion of "society," the bounds of which will be discussed, and is

${ }^{1}$ The ratio of the (full-time, year-round) wage of white women to that of white men increased from 0.605 to 0.739 between 1980 and 2000, and that for all 25- to 34-year olds with four years of college increased from 0.739 to 0.833 between 1980 and 1995. Source: Current Population Survey, Outgoing Rotation Groups. A standard measure of occupational segregation (the dissimilarity index) decreased from 0.64 in 1960 to 0.51 in 1990 using a consistent set of 238 occupations and from 0.73 in 1960 to 0.62 in 1980 using 12,850 occupation-industry cells (Jacobsen 1994, table 1). Despite these large gains, most studies of wage and occupational differences still find an unexplained gap, although the differential and the unexplained portion have both decreased over time. See, for example, the literature review provided by Altonji and Blank (1999) and, for long-term trends, Goldin (1990).

${ }^{2}$ The earliest treatment, as well as the most cited, is Becker (1957). 
based on the level of a productivity-related characteristic (e.g., strength, skill, education, ability) that originally defines the minimum needed to enter a particular occupation. But prestige can be "polluted" by the entry of an individual who belongs to a group whose members are judged on the basis of the group's average and not by their individual merits. ${ }^{3}$ Men in an all-male occupation might be hostile to allowing a woman to enter their occupation even if the woman meets the qualifications for entry. The reason is that those in the wider society will not know that the woman was qualified and might, instead, view her entry as signaling that the occupation had been altered. She will be seen as "polluting" the occupation. ${ }^{4}$

The reason that her entry might be a signal of change in the standards for admission is because the economy is dynamic. Technological change can reduce the minimum level of the characteristic required for entry. For example, firefighters once had to be strong enough to carry extremely heavy and unwieldy equipment. The advent of lighter hoses diminished the actual physical strength required (although it remains far higher than that for most jobs). Society has imperfect information regarding changes in technology and infers change from observables. One of these observables is the sex (or any group descriptor, such as race) of new entrants. Thus men might want women barred from their occupation to protect their status even if no skill-reducing technological change affected their occupation. Whether or not men in a previously all-male occupation will want to bar the entry of women will depend on the distribution of the productivity-enhancing characteristic in the male and female populations and the minimum level

\footnotetext{
${ }^{3}$ The term "pollution," in this context, is from the anthropological literature and originates in the works of Mary Douglas (Douglas 1966). Women, across many cultures, are separated from men during menstruation, and sexual intercourse is thought to pollute men. These beliefs enforce, and perhaps reinforce, the separation of the sexes in production and consumption.
} 
of the characteristic initially required for the occupation in question. Asymmetric information is a key feature of the model. ${ }^{5}$

The model contains predictions about the relationship between occupational segregation by sex and earnings (or the level of the characteristic). The prediction is that sex segregation will be greater for occupations containing women with higher levels of the characteristic and that segregation, perhaps surprisingly, can be non-monotonic with respect to the characteristic.

Occupations are most likely to be segregated at the tails of the female characteristic distribution but integrated somewhere toward the middle, generally just below the median of the female characteristic distribution. Occupations requiring a high level of the characteristic will not be integrated unless society has verifiable information regarding qualifications.

The model also suggests how discrimination and earnings respond to changes in the distributions of the characteristic and why knowledge of past distributions helps explain current gender distinctions in the labor market. Evidence consistent with these predictions is presented for various time periods. The model is inherently historical - the past affects the present within individual experiences and within the labor market.

Alternative assumptions have also embedded the original insights of Becker in explicit taste-based models of sex discrimination. In hierarchical models men require a premium to work with women who have higher occupational status or authority. Other frameworks posit that interactions between men and women reduce productivity because of communication obstacles

\footnotetext{
${ }_{5}^{4}$ See Akerlof and Kranton (2000) for a related model on the protection of identity.

5 The type of "asymmetric information" in this model differs from that in most others in which managers have incomplete information about worker ability. In this model, the asymmetry comes from incomplete information by those who confer "prestige" on workers and the group who confers prestige is "society."
} 
or the exact opposite-flirting, jealous spouses, sexual tension, and so on may decrease output or profits. ${ }^{6}$ Several versions of the statistical theory of discrimination exist in which men and

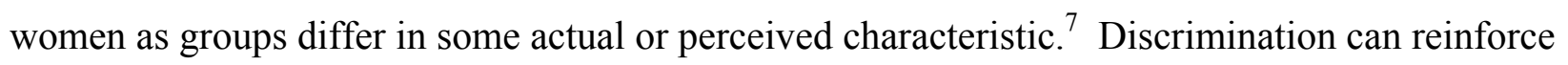
these skill disparities or result in differences in promotion if certain workers are more visible than others. ${ }^{8}$

The pollution theory of discrimination is complementary to other models of discrimination and can be viewed as a hybrid of Becker's original "taste" model with that of statistical discrimination. Put another way, it posits that male employees discriminate against prospective female employees as a way of protecting their prestige in an asymmetric information context. The pollution theory model contains various predictions that are not contained in other models and serves to explain historical features of the labor market that others cannot. A more formal version of the model will make the assumptions and implications clearer.

II. A Pollution Theory of Discrimination

\section{A. Model Setup}

Assume there is a productivity related, single-valued characteristic $(C)$, such as strength, skill, education, or determination. The attribute need not be inherent. It can be acquired and can

\footnotetext{
${ }^{6}$ See Lang (1986) on communication. Humphries (1987) considers the explicit problem of sex in the work place. On the latter, see also Breckinridge (1906), who noted "it is well known that the unregulated mingling of men and women under conditions of darkness, fatigue, or the excitement due to the constant apprehension of danger may give rise to immoral intercourse. On this account we find women generally prohibited from working in mines, and ... other forms of employment at night” (p. 107).

${ }^{7}$ On statistical discrimination see Arrow (1973) and Phelps (1972), and the interpretation given by Aigner and Cain (1977).

${ }^{8}$ See Lundberg and Startz (1983) on discrimination and incentives to acquire skill and Milgrom and Oster
} 
be altered by complementary factors such as machinery. ${ }^{9}$ The characteristic is distributed, perhaps differentially, among men and women. The distribution of $C$ for males, but only the median for females, are known by all workers as well as all others in society. ${ }^{10}$

The model contains two periods. In period 1 only men have labor market jobs, known as "occupations," and women are in the home. Men remain in the same occupation in period 2 and women enter the labor force in period $2 .{ }^{11}$

Every occupation, $i$, requires a minimum level of $C$, and no one with $C$ below $C_{i}$ can produce at all in occupation $i$. Productivity in occupation $i$ rises with $C$ above $C_{i}$. Workers are paid according to their productivity, that is their level of $C$ and will therefore sort into occupations. In equilibrium, therefore, each value of $C_{i}$ in period 1 defines one and only one "occupation" for men. ${ }^{12}$

Men receive utility from both the income, $\left(Y_{i}\right)$, and prestige of their occupation, $\left(C^{*}{ }_{i}\right)$,

(1987) on visibility.

${ }^{9}$ The characteristic can, for example, be thought of as one's strength rating on a particular machine. Refinements to the machine can lead weaker individuals to be measured as stronger. The characteristic can also be a skill or an education level that can be augmented over time.

${ }^{10}$ Endowing individuals with the knowledge of both distributions can cause problems with the assumption that the entrance of a woman into an all-male occupation provides information about the nature of the skills used in that occupation. Individuals might then be able to figure out the "correct" number or proportion of women who ought to be in each occupation, given that no occupations above it in the skill distribution are "discriminating." To get around this problem, one can endow individuals with the knowledge only of the female median. In the case of the symmetric form of the model (given in a footnote below), knowledge of the entire distributions is needed.

${ }^{11}$ I do not directly consider why women enter the labor market in period 2. One possibility is that the characteristic distribution for women shifts to the right because of increases in education or complementary physical capital. The justification for why men remain in their period loccupations in period 2 might be that there is specific human capital or large moving costs.

${ }^{12}$ In this simple set up there is no capital, and the workers are "hired" by an entrepreneur who is the first entrant in the occupation. 
where prestige is person $i$ 's characteristic as perceived by society. ${ }^{13}$ Women receive utility from the income of their occupation in period 2 and the value of their home production in period 1 , although that will be ignored here.

But — and this is crucial - because the world is dynamic, an occupation may not require the same level of $C$ in period 2. Technology shocks, $\Omega$, all of which are negative, occur between periods 1 and 2. Each occupation randomly draws a value of $\Omega$ that is either 0 or 1 . The shock, therefore, either lowers the minimum level of $C$ required for an occupation or leaves it unchanged. The value of $\Omega$ for occupation $i$ is known only to those in occupation $i$ in period 1 . Women enter the labor market in period 2 and apply to the various occupations.

Thus for men in period 1: $U^{M, 1}=U^{M}\left(Y_{i}^{1}, C_{i}^{*, 1}\right)$, which is equivalent to $U^{M, 1}=U^{M}\left(C_{i}^{1}, C_{i}^{*, 1}\right)$, since income is a function of the actual level of $C$ and thus the occupation in period 1. In period 2, however, $U^{M, 2}=U^{M}\left(Y_{i}^{2}, C_{i}^{*, 2}\right)$, which may not be equivalent to $U^{M, 2}=U^{M}\left(C_{i}^{1}, C_{i}^{*, 1}\right)$ if $\Omega=1$. Whatever the value of $\Omega$, men will want to maintain their level of prestige. Prestige, $C^{*}{ }_{i}$, arises from how society views the $C$ level of an individual's occupation. The level of $C$ associated with an "occupation" in period 1 is known to everyone, but only those in the occupation know whether $\Omega=1$. Since male workers remain in their period 1 occupation for both periods, even if $\Omega=1$, their income can decrease. But even if their income decreases, their prestige can remain just as it was in period 1.

It is useful to review the informational asymmetries in the setup: what is known to all, to

\footnotetext{
${ }^{13}$ Prestige is different from income or from one's position in the income distribution. But prestige might also be thought of as a signal of one's income-earning ability, as in the case of a man who is turned down for a loan because the loan officer thinks the man's occupation has undergone a loss in income-generating
} 
each individual, and to those in an occupation in each of the two periods. The variables known to all — common knowledge — are: the distribution of $C$ for men, the median of $C$ for women, and the minimum value of $C$ required for all occupations in period 1 , that is $C_{i}{ }^{1}$. Everyone knows his or her own $C$, but only those in occupation $i$ in period 1 know the value of $\Omega$, that is only they know $C_{i}^{2}$.

At this point it is convenient to assume, as well, that the demand for all goods is perfectly elastic and that the production technology is characterized by constant returns to scale. The "small country" and production technology assumptions ensure that the wage does not depend on the number of individuals in the occupation and, consequently, that there can be no wage effects or "crowding."" These assumptions are relaxed below. They simply ensure that a simple version of employee discrimination - the protection of income - is not confused with the protection of prestige in the "pollution theory" setup.

Because of the informational asymmetry concerning $\Omega$, the prestige or status associated with being a weaver, printer, doctor, or widget-maker depends on the identity of new workers even if $\Omega=0$, that is even if there has been no actual "deskilling." The entry of an individual who comes from a group known to have a lower average level of the skill may signal the "deskilling" of an occupation even if nothing changed. Individuals outside the occupation do not know whether the "test" or criterion for entry has changed, and it is costly for them to obtain such information (e.g., trying out for the occupation). Society is the arbiter of prestige and

ability.

${ }^{14}$ Assume the production function is of the form $Q=\lambda \cdot L \cdot C_{i}$, where $L$ is the number of employees, and $C_{i}$ is the minimum characteristic level of the occupation, and that each unit of $Q$ sells at the exogenous price $P$. Therefore the value of the marginal product, and thus the wage, is a function only of $C_{i}$. 
updates its information about the $C$ level required for the occupation by observing the median characteristic of a new entrant.

Women do not know which occupations have been hit by the negative technology shock, and thus they cannot limit their search to those whose minimum $C$ level requirement they would have met in period 1. The $C$ level of an individual woman is known only to her and can be discerned only by administering a test. Thus the employer for an occupation can determine whether a woman meets the minimum requirements, and once on the job, her fellow colleagues (all men) can also see that she is qualified. But society does not know her qualifications. Had no technology shock occurred between periods 1 and 2, society would know that the female applicant had precisely the same $C$ level as the men already in the occupation. But society does not know whether the value of $\Omega$, and the technology shock adds a critically important degree of uncertainty. The question, therefore, is whether the male workers in occupation $i$ will resist the introduction of a woman or whether they will be pleased to have her.

B. Model Equilibrium and Implications: Identical Characteristic Distributions The characteristic or $C$ distributions for men and women can be identical or can differ, as would be the case if strength were an important part of productivity. It is likely that these distributions changed over time, for example, with the introduction of machinery, the substitution of "brain" power for "brawn" power, and changes in educational attainment.

The $C$ distribution for women is given by $g\left(C^{F}\right)$ and that for men is given by $h\left(C^{M}\right) \cdot{ }^{15}$ Assume for the moment the gender-neutral case in which the $C$ distributions are identical for men and women, thus $g\left(C^{F}\right)=h\left(C^{M}\right)$, as in Figure 1 where the median $C$ level is given by $F$. 
Recall that only men are employed in occupations in period 1 and that each value of $C_{i}$ defines an occupation in equilibrium. Because the characteristic distributions are identical for men and women, women can produce at the minimum required in each occupation. The question is whether men will allow women into their occupation in period 2.

Consider a male employee with a characteristic value somewhere in region $F E$, for example $H$. What is his response to hiring a woman into his occupation? Recall that everyone knows that an $H$-level of the characteristic is required for the occupation in period 1 , and the worker's status is related to society's perception of his characteristic value. Thus in period 1 his utility is given by $U_{H}^{M, 1}=U_{H}^{M}\left(Y_{H}^{1}, C_{H}^{*, 1}\right)$.

The world is dynamic and an occupation's level of $C$ can be altered by a technological shock, such as the introduction of machinery that reduces skill requirements. Handloom weavers required considerably more skill than did factory weavers, and cobblers required more skill than did workers assembling shoes after the introduction of the sewing machine. One's status can actually be reduced in a dynamic world. But it can also be polluted in a manner that is more apparent than real—by the hiring of workers whose median level of the characteristic is lower than that currently required in the occupation. The introduction of such workers is a signal that the occupation probably underwent change in its skill requirement, even when it did not. ${ }^{16}$

Returning to whether the worker at $H$ would oppose a woman in his occupation, consider the type of signal that hiring a woman would provide and recall, as well, that the $C$ level of a particular woman is private information. Assume that society picks a decision rule such that

\footnotetext{
${ }^{15}$ Only the median for the female distribution has to be known.

16 This notion of pollution is similar to "tipping" in housing segregation models.
} 
probabilities below 0.5 signal a technology shock, that is they signal $\Omega=1$, and that those above do not, that is they signal $\Omega=0$. If a female applicant is accepted into the $H$ occupation, society infers whether the occupation underwent change, between periods 1 and 2 , by calculating whether:

$$
\int_{i=H}^{E} h\left(C^{F}\right) d C_{i}<0.5
$$

that is, whether $H$ is above or below the median value for women. In the case under consideration, the probability that the attribute value, $C$, of a randomly drawn female applicant is greater than $H$, the current value, is less than 0.5 . Thus society will infer that the occupation has drawn a value of 1 for $\Omega$, and all men in the occupation will suffer a loss in prestige if a woman enters the occupation. Even if $\Omega$ were actually 0 , women will be barred from entering occupations above the female median to protect that status of existing male workers. Thus male workers above the median of the female distribution will oppose the entry of women in their occupation and those below the median will not.

As in the classic Becker model of discrimination, men in the range $F E$ will demand a premium to fully compensate them for the loss in prestige if women are hired. The premium would increase with the distance from $F$ if the reduction in prestige was a constant, thus independent of $C_{i}$, and the premium would be less costly the fewer men in the occupation. ${ }^{17}$

\footnotetext{
${ }^{17}$ The wage premium demanded can also be modeled as a function of the probability that the randomly drawn woman is less qualified, with lower probabilities demanding less compensation. Note that the occupation could be defined by place, firm, industry or some other means. If individual male machinists, for example, perceive their prestige to depend on the existence of female machinists in any firm, there would be an externality imposed by some firms on the workers in others. Occupations that are rare across firms will be less likely to be segregated than those that are numerous within firms since all workers suffer the same loss in prestige and total compensation will be greater the more workers there are to compensate.
} 
Rather than fully compensate the men in the occupation for their loss of prestige, it may be less costly to create another occupation for women (at the same level of $C$ ). Two occupations having the same minimum level of $C$ can exist within a firm, one for men and another for women (e.g., waiter and waitress; seamstress and tailor; doctor and nurse practitioner). But there may be a cost advantage within a firm of having only one occupation for each level of $C$. Alternatively, one firm can have only men do a job and another firm can have only women do the same job.

In a competitive equilibrium women will be paid the same as men having equal characteristics, but they will be in a different firm or in a different "occupation." Two occupations, or two firm-occupations, will exist that use the same level of skill. They will be found at levels of $C$ above $F$. The creation of these all-female occupations could take considerable time. In the meantime, women will be "crowded" into occupations for which they are "overqualified," and these overqualified women will be found above the median of the female distribution.

Consider, instead, a male worker at point $G$. That worker will not perceive his status or prestige polluted if a woman is hired into his occupation. Using the rule set down in equation (1), the probability that the new (female) worker has an attribute value exceeding that of the initial workers is greater than 0.5 . Men in occupations below the median of the female distribution will find that women do not pollute their status, and these occupations will be integrated. The symmetrical version of the model predicts that occupations will be segregated in range $F E$ and integrated in range $A F$.

C. Model Equilibrium and Implications: Dissimilar Characteristic Distributions The characteristic distributions may not be identical for men and women or may have 
been dissimilar in the past but not now. An extension of the basic model allows the distributions to be different at the start, but progressively less so. The implications are similar yet more revealing about the historical process of sex segregation.

The characteristic distributions of men and women may have been so divergent at some distant time that they were non-overlapping. The ratio of female to male wages in New England farm communities around 1800 , for example, was extremely low, probably below 0.30 , and men and women were rarely employed at the same tasks. ${ }^{18}$ Given the technology, crop, inherent differences between the sexes, and possibly social custom, women had considerably lower relative productivity in the work force. ${ }^{19}$ The industrial revolution in America, beginning around the 1820 's, may have shifted the female characteristic distribution to the right and possibly widened both distributions through the differentiation of tasks. A further shift can be associated historically with the increase in education in the first decades of this century and the evolution of occupations, such as those in the clerical, sales, managerial, and professional sectors, that had higher returns for schooling than did those in manufacturing. As brain power replaced brawn power, the two distributions may have become more similar, if not identical.

In this version of the model, given in Figure 2, the two characteristic distributions are overlapping but not identical. Similar to the setup before, men are hired into jobs in period 1, say in the manufacturing sector, and they receive occupations depending on their level of $C$. Women try to enter occupations in period 2 and men respond.

\footnotetext{
${ }^{18}$ See the evidence in Goldin and Sokoloff $(1982,1984)$, also Bidwell and Falconer (1925).

${ }^{19}$ Another way of justifying why the female distribution of the characteristic may be to the left of that of men is that until the 1940's both married and single women in the paid labor force (outside the home) were drawn from the less educated portion of the female population. Thus even though the male and
} 
Two regions in Figure 2 are of interest and two are not. Only women will be employed in $A D$ and only men in $B E$. Just $D F$ and $F B$ (where $F=$ the female median), offer the possibility of integration. The model predicts that occupations will be segregated by necessity in range $A D$, integrated in range $D F$, segregated by design in $F B$, and by necessity in $B E$. Only in range $F B$ will there be both male and female occupations and these can be segregated occupations within a firm or firms hiring either men or women do so the same occupation.

Now consider a shift of $g\left(C^{F}\right)$ to the right, resulting in $g^{\prime}\left(C^{F}\right)$ in Figure 3, as may have occurred with the increase in education during the first decades of this century. What is the response? In the long run the result must be identical to that outlined above. Segregation will exist from the new female median at $F^{\prime}$ to $E$ and the range of integration will be larger by $F F^{\prime}$. Certain occupations, those in range $A A^{\prime}$, will disappear and others, those in range $B B^{\prime}$, might be added. But there are several reasons why the long run may take considerable time and why the path to the long run may be the most interesting.

The areas of greatest change will be $F F^{\prime}$, the new integration range, and $B B^{\prime}$, the new occupation range. Male workers in range $F F^{\prime}$ might resist integration with prospective female employees if they do not know that the median of the female characteristic distribution has increased, or if they believe that others do not yet know. Once everyone knows the median of the new female characteristic distribution, men in range $F F^{\prime}$ will not be polluted by the presence of women colleagues and will let them enter. In the interim, women in range $F F^{\prime}$ will remain in pre-existing "female-only" occupations, should those occupations have been set up.

Women in the range $B B^{\prime}$ will not be able to enter the male occupations for which they are 
qualified and will have to enter newly created "female-only" occupations. If the creation of these occupations takes time, they will be "crowded" into the next best alternative in the interim - the occupation at point $B$. Under the "small country" and constant returns assumptions, wages will not change. But some female workers will be earning too little given their characteristics. Economic "wage discrimination" will be picked up by econometric studies, but jobs will receive the correct remuneration given the requirements for the occupation. ${ }^{20}$

D. Wage and Feedback Effects

Dropping either the assumption of exogenous prices or that of constant returns to scale leads to wage effects. Integrated and female-only occupations will have changed wages as the relative supply of workers is altered across the attribute spectrum. The number of workers will increase to the right of point $X$, the crossing point of the previous and new female distributions in Figure 3, and a decrease to the left. As a percentage of previous workers, both the increase and the decrease are greatest at the tails $\left(A^{\prime}\right.$ and $\left.B^{\prime}\right)$ and diminish moving in from both to $X$. If the change in the wage depends on the percentage increase in workers, the wage will rise most at $A^{\prime}$ with diminishing impact as one moves toward $X$. Similarly, the wage will fall from $X$ to $B^{\prime}$ in an increasing fashion. Male workers to the right of point $X$ have the most to fear from the introduction of female workers and this will increase moving toward point $B^{\prime}$. Note as well that if workers with similar skills produce goods that are close substitutes, even workers in range $B^{\prime} E$ will face changed wages with a shift in the skill distribution.

There will be additional wage effects around point $B$ if the female-only occupations in

\footnotetext{
${ }^{20}$ Under these circumstances, a comparable worth policy will not eradicate discrimination but an affirmative action policy might; however see Coate and Loury (1993) on the potential for such a policy to
} 
range $B B^{\prime}$ take time to emerge. Individuals in jobs located between $F^{\prime}$ and $B$ and all female workers in range $B B^{\prime}$ will be paid too little given job requirements and individual attributes.

The absence of women from the upper tail of the occupational distribution, range $B B^{\prime}$, even during an interim period may have a lasting impact on the perceptions of all workers about the characteristic distribution of women and about occupations that are "appropriate" for young women. If, for example, the characteristic is education and $B$ is "teacher," then women with education levels in $B B^{\prime}$ will be teachers rather than principals, lawyers, and doctors. Young women will not have an incentive to attain higher levels of education. The nurse in range $F B$ may once have been appropriately placed initially, albeit in a sex-segregated occupation. But at a subsequent date women with a higher level of the characteristic may be inappropriately trained to be nurses due to an absence of opportunities in range $B B^{\prime}$ or to their perceptions of an appropriate career for women. Occupational segregation by sex may produce appropriate financial rewards at one date, but may lead to unfair rewards and incorrect expectations at a later date.

Occupations in range $F B$ (and later in $F^{\prime} B$ ) may become "protected," either through actual barriers to entry or through rhetoric that creates an aura of gender. Firms may be able to attract men into an occupation only if they can promise that the occupation will remain "male only." Once in an occupation, men in range $F B$ have an incentive to use rhetoric and construct a set of norms that inform prospective entrants (and employers) of the occupation's gender, even if the occupation can be performed by either sex. At times this involves the creation of, what may

backfire even when the two groups are identical. 
be called, "secondary sex characteristics.,"21

Becker's keenest insight in his classic discrimination model is that the economic marketplace has an ameliorative impact and that occupational segregation can substitute for the wage effects of discrimination. But occupational segregation may not be a benign consequence if the present affects the past through the formation of expectations, through the appearance of "holes" in the occupational spectrum, and through the institutionalization of barriers. If men infer the median of the female characteristic distribution from the distribution of occupations containing women, adjustment lags—caused by pre-existing norms, barriers, and slow informational flows - will lead to an underestimate of the new median for women. This underestimate will lead a greater proportion of men to be hostile to female entrants. Programs and policies that make highly educated and successful women, of the present and past, more visible, serve to counteract the effect.

E. Further Results and Clarifications to the Pollution Theory Model

In the simple form of the model, discrimination and occupational segregation will occur even if the distributions of male and female characteristics are equal. Male employees will treat a female applicant as a "polluter" in occupations above the median and these will remain maleonly occupations. The result arises because men enter the occupations in period 1 and women apply to enter only in period 2 .

The model can easily accommodate a symmetric treatment in which both men and women apply for jobs in period 2, although only men enter in period 1. As in the previous setup, no one outside the occupation knows the $C$ level of the prospective entrant although everyone

${ }^{21}$ See Goldin (1990). Pollution Theory 16 
knows the $C$ level of the occupation in period 1 . Between period 1 and 2 , there is a technology shock $\Omega$ that introduces uncertainty regarding an occupation's $C$ level.

The more fully symmetric form of the model treats each new entrant, either male or female, as a potential "polluter." Let $\beta=$ the probability that a male does not pollute, and $\alpha=$ the probability that a female does not pollute, an occupation known to have a $C$ level of $\lambda$. Using the notation of Figure 2: $\int_{\lambda}^{B} g\left(C^{F}\right) d C=\alpha$, and $\int_{\lambda}^{E} h\left(C^{M}\right) d C=\beta$ where, generally, $\beta>\alpha$. Assume that pre-existing male workers in the occupation require compensation for hiring a female and that this compensatory payment increases with $[(\beta-\alpha) / \beta]$. That is, the payment increases with the difference in the probabilities that a male and female will not pollute scaled by the probability that one of their own — a male — will. The level of compensation required to hire a female worker will rise with $\lambda$, the preexisting $C$ level for male employees. ${ }^{22}$

The results, therefore, conform to those of the asymmetric form of the model, but the compensation demanded will go to zero as the two distributions approach each other and will be zero when they are equal. The results will be qualitatively identical to those obtained with the assumption that only women apply for the jobs in period 2, but the range of integrated occupations will widen for any two distributions and will widen progressively as the two distributions approach equality.

The model can be extended to account for different probabilities that a technological shock, $\Omega=1$, occurred, although there will be little change to the substantive results. Some occupations, firms, and industries will face a higher probability that $\Omega=1$ and this could enter

\footnotetext{
${ }^{22}$ As in the previous discussion, the amount of compensatory payment will depend on the number of
} 
the probability that a female entrant is a polluter.

Similarly, the model can be extended to incorporate the total costs of hiring a woman. In the current model, even one female employee will "pollute" all male workers in the occupation. The cost of hiring would therefore have to include the total amount of compensation given to pre-existing male employees and that would rise with the size of the occupation within a firm. Thus, occupations that are relatively large within firms will be more costly to integrate. ${ }^{23}$

In sum, the implications of the model are that occupations above the median of the female distribution will be segregated and that occupations may be segregated in a nonmonotonic fashion with regard to the attribute and the wage. For some distributions of the attribute, occupations will be segregated in the tails and integrated in the middle of the female distribution. For other distributions, in which the male and female distributions fully overlap at the bottom of the characteristic range, there will be integration at the lower end and segregation at the upper end. And in the upper range, male-only occupations will develop barriers against female entrants.

\section{Taking the Model into the Real World}

Exactly how one takes the model to the real world depends on the spatial boundaries of human association. Male firefighters or police officers, to take two examples, may perceive their status to depend on the sex composition of their own police station or firehouse. Some, however,

male workers since the hiring of just one woman pollutes the prestige of all men.

${ }^{23}$ Other extensions of the model include: (a) including period (3) to allow men to shift out of occupations 
may believe that their stake encompasses a wider geographic area, such as the municipality or the state. Thus, if employees in an occupation are scarce within firms (e.g., bookkeepers in small offices, teachers in rural areas), there can be wide differences in the gender of an occupation across space. Much will depend on whether employees have knowledge of their counterparts in other firms and view them as equals, as well as whether their status is conferred by the same societal group.

Certain assumptions can be amended in application, in particular that a specific female entrant's $C$ level is unknown to society. The degree to which her admission into the occupation will "pollute" the status of existing male workers is dependent on the assumption that she is viewed as a random female applicant. The credentialization of occupations (e.g., the necessity for degrees, licenses, admission tests) in the upper end of the characteristic distribution could eliminate the negative signal provided by hiring a woman particularly if the credential were well known and verifiable. The absence of occupations that use women's talents (the "overqualified" female candidate) can result in inappropriate wages ("wage discrimination") given characteristics and can reinforce discrimination. Credentialization could eliminate these effects.

The model developed here explains why men object to women's entering their occupations apart from their desire to maintain wages. Several reasons have motivated the construction of the model in this fashion. For one, it is too obvious that individuals and groups object to having their earnings depressed and their jobs endangered. Union members erect barriers to entry even when the prospective hires are of the same sex, race, and ethnicity. Nationals want to restrict immigration to protect their earnings and jobs. 
Men have objected to having women in their occupation even when earnings could not have been depressed their entry and in cases even after earnings were eroded by changes in either supply or technology. Men objected to female manufacturing workers during World War II even though men were promised "equal pay for equal work." 24 In other cases the number of women attempting to enter the contested occupation was far too small to have depressed wages by more than a trivial amount. Finally, there are examples of all-male occupations in which relative wages for the occupation decreased long before women were allowed to enter. Women were employed as bank tellers as an emergency measure during World War II, even though the relative wages of male bank tellers had already decreased a decade or more earlier. ${ }^{25}$

To demonstrate the potential importance of the pollution theory, I explore the historical record to find evidence concerning the empirical propositions derived from the model. The propositions are related to occupational segregation and its change over time, the relationship between occupational segregation and the characteristic (or earnings) distribution, the degree of and emergence of "wage discrimination," and the role of credentialization and incentive pay in integrating occupations by sex.

A. Occupational Segregation: Origins and Maintenance

Historically, occupations have been highly segregated by sex. A national index of dissimilarity across all occupations remained fairly constant at about 0.66 from 1900 to 1950 , whereas that for the non-farm labor force fell from about 0.75 to 0.67 . Ever since 1950 the index has steadily declined and for the non-farm labor force it now about a third lower than it was a

\footnotetext{
${ }^{24}$ See the discussion in Milkman (1987).
}

${ }^{25}$ Strober and Arnold (1987). 
half century ago. ${ }^{26}$

Although some occupations have changed sex over time (e.g., librarians, bank tellers, teachers, telephone operators, sales positions), new occupations and new industries (e.g., some clerical positions in the 1910s, electrical machinery operatives in the 1920s) as well as those experiencing substantial growth in demand (e.g., teachers in the nineteenth century) are most likely to become "feminized." 27 Several occupations that were integrated by necessity during wartime were quickly feminized thereafter (e.g., bank tellers) whereas others returned to being male dominated (e.g., craft positions in manufacturing). Some occupations were feminized slowly and incompletely across firms and spatially (e.g., sales, teaching), while the process was swift and complete in others (e.g., telephone operators).

Most occupations are not inherently male or female. Instead, they often gain an "aura of gender" through a rhetoric that surrounds the labor market, by the evolution of certain norms and the use of particular forms of physical capital. The origin of these differences can often be found in factor endowments, as well as other factors.

Dairying in the early nineteenth century, for example, was considered men's work in the East but women's work in the Midwest, where a male milker was thought to be doing "women's work." Farmers in the East had smaller farms and less fertile land than in the Midwest. Thus male agriculturalists in the East had little else to do than milk cows and run the dairy. Factor

\footnotetext{
${ }^{26}$ On long-term trends in occupational segregation using a consistent set of occupations for the entire economy and the non-farm sectors, see Jacobs (1989). A more relevant index, particularly for the model developed here, would use firm- or city-level data. Blau (1977) analyzes the effects of sex segregation using data on the fraction female by firm for occupation-city cells.

${ }^{27}$ Garrison (1979) notes that male librarians became administrators during the period of demand growth. On more recent changes in occupational segregation see Reskin and Roos (1990).
}

Pollution Theory 21 
endowments influenced gender roles. ${ }^{28}$

For example, when typists were primarily men, it was claimed that typing required physical stamina. But later, when typing became a female occupation, it was said to require a woman's dexterity. ${ }^{29}$ Meatpacking and slaughtering establishments in the 1890 s had virtually all male labor forces who claimed that women should not be employed in the trimming-room and cutting floor because "handling the knife" was not women's work. The use of female strikebreakers in 1904 ultimately led to the hiring of women in sausage making. But even though Slavic women were hired as meat trimmers, women were not given entrée to the cutting floor. $^{30}$

As Caplow (1954) has noted in his insightful work on occupations, "Any job for which only women are employed is likely to be classified as delicate, or even as monotonous."31 Occupations and industries acquire "secondary sex characteristics" that serve to reinforce small initial differences in the degree of strength, stamina, or intensity demanded on the job. "The use of tabooed words, the fostering of sports and other interests which women do not share, and participation in activities which women are intended to disapprove ... all suggest that the adult

${ }^{28}$ Although see Bidwell and Falconer (1925, p. 116) on the work of farmwomen on colonial New England. According to most accounts, native-born women did not work in the fields but did some dairying ("In New England only men ... were to be seen in the fields"). Recent arrivals from Germany, however, worked alongside their husbands and brothers in the fields. Once again, factor endowments and income levels altered gender roles.

${ }^{29}$ See Davies (1982).

${ }^{30}$ See the account by Abbott and Breckinridge (1911). "There seems to be a strong objection in the community to the employment of women in the trimming-room, on the ground that 'handling the knife' is not women's work. It is difficult to justify this prejudice on any logical ground since it has always been recognized that a woman could suitably handle a knife in her own kitchen" (p. 639). Although women linked, twisted, and tied the sausage after the strike, the packing of sausage in the casing, which used machinery, remained men's work.

${ }^{31}$ Caplow (1954, p. 233). 
male group is to a large extent engaged in a reaction against feminine influence."32

Union rules and firm policy have also been used to restrict the entry of women. Unions have erected barriers to the hiring of women in various crafts. Molders working in foundries in the 1910 s were fined for instructing women in their trade. ${ }^{33}$ The Cigar-Maker's International Union, organized in 1851, excluded women (and blacks) in its constitution. ${ }^{34}$ Rigid, formal barriers have existed in many professions, such as law and medicine. ${ }^{35}$ Firms hiring office workers in the 1920's and 1930's had personnel policies not to hire women in certain occupations but to hire women exclusively in others. ${ }^{36}$

When women manage to slip through the barriers, intimidation is often a last resort. Female firefighters and police officers have successfully sued municipalities for sexual harassment with intent to create a hostile work environment and for tampering with tests to make women, but not men, fail. ${ }^{37}$ Abbott tell of a woman and her daughters who learned to use the

${ }^{32}$ Ibid., p. 239, italics in original.

${ }^{33}$ U.S. Department of Labor, Women's Bureau (1920) reported that: "The molders' union did not admit women even during the war ... By the rules of this organization members are fined for teaching a woman any part of a trade ... A further reason is the fact that core making ... is regarded as one of the stages in the apprenticeship of a "molder." Unless all the stages ... are open to women the introduction of woman core makes complicates and disrupts trade regulations" (p. 34). See also Kanter (1977) on the training of managers by others within firms.

34 Abbott (1907, p. 16). The union altered its constitution in 1867 to allow the excluded groups to become members. A decade later, in 1877, women were used as strikebreakers.

${ }^{35}$ See Morello (1986) on lawyers and Harris (1978) on professions in general.

${ }^{36}$ See Goldin (2002).

${ }^{37}$ There have been several high-profile cases involving firefighters and police officers. In Berkman v. City of New York (U.S. District Court, 626 F. Supp. 591, 1985), two female firefighters were physically harassed and the physical test for advancement from the probationary position was altered. Three female firefighters successfully sued the Reedy Creek Improvement District and Walt Disney World (The Orlando Sentinel, October 29, 1996, p. D1) for harassment. Male firefighters had displayed lewd pictures of women in the fire station and engaged in vulgarities, all of which prevented women from receiving training. In Ramona Arnold v. City of Seminole, Oklahoma (U.S. District Court, 614 V. Supp. 853, $1985)$ police officers sexually harassed a female officer with intent to create a "hostile and offensive 
mule in a Waltham textile mill but were forced to leave when the "men made unpleasant remarks." ${ }^{38}$ Firm managers and supervisors interviewed at the end of both world wars noted that it was virtually impossible to integrate occupations incrementally from 100 percent male. ${ }^{39}$

But even though credentials and tests may initially be barriers to women's entry, a woman who has earned a verifiable and known credential or passed a test of known quality cannot be viewed as a polluter. Thus the growth of the credentialized sector can increase integration and reduce "wage discrimination."

B. Manufacturing Occupations in the Early Twentieth Century

Occupations and industries have been overwhelmingly segregated by sex throughout history, although segregation was more extreme a century ago than it is today particularly in manufacturing. ${ }^{40}$ Integrated occupations in manufacturing around the turn of the twentieth century were found in a handful of industries (viz. textiles, apparel, tobacco, shoes, printing, paper). Further, when men and women occupied the same job in the same firm, remuneration was invariably by the piece, not time. Piece-rate work may have enabled firms to pay males and females different amounts despite having the same occupational title and working in the same firm. For example, male piece-rate compositors who worked in integrated firms - those having both male and female compositors - earned on average 36 percent more than did female piecerate compositors. $^{41}$

working environment."

${ }^{38}$ Abbott (1909, p. 92).

${ }^{39}$ See U.S. Department of Labor (1920). This was particularly true of firms having a large number of men in an occupation.

${ }^{40}$ See, for example, the discussion in Goldin (1990), chapter 3.

${ }^{41}$ Goldin (1990), table 3.6, p. 81. 
Many industries in the early 1900s had no integrated occupations, and a large and important group (hiring more than 60 percent of all male operatives) had virtually no female operatives. Industrial segregation by sex, in the manufacturing sector, as measured by an index of dissimilarity was 61 in 1890 but fell to 33 in $1960 .{ }^{42}$ Industries were so highly segregated in 1890 that more than 60 percent of male operatives could not have shared the same industrialoccupational title with a female. Virtually no female operatives were employed in 23 "male intensive" industries (e.g., agricultural implements, iron and steel, lumber) in 1890. Of the 230,000 production workers in foundry and machine shop products in the United States in 1890, just 1,200 were women. Almost 70 percent of all female operatives were in just two industriestextiles and clothing. ${ }^{43}$

Yet "wage discrimination" was rather small among male and female operatives across the manufacturing spectrum around $1900 .^{44}$ Attribute differences (e.g., total work experience, years in the occupation, tenure on the job) explain much (65 percent) of the disparity in earnings and another portion is due to differences in the productivity of unskilled men and women paid by the piece (15 percent). ${ }^{45}$ Despite the introduction of machinery throughout the manufacturing sector, brute strength was still important and highly rewarded. All of this suggests that the male and female distributions of $C$ were rather far apart in 1890. But these facts cannot explain all industrial and occupational segregation.

\footnotetext{
42 The index of dissimilarity is used where the unit of observation is the two-digit SIC industry in 1890 and 1960. See Goldin (1990), table 3.5, p. 80.

${ }^{43}$ U.S. Census Office (1895), also Goldin (1990), table 3.5, p. 80.

44 On "wage discrimination" see Goldin (1990), chapter 4.

45 The 15 percent figure comes from an analysis of the earnings of men and women in the same occupations (in this instance it was the bundling of kindling wood), paid by the piece in firms that hired
} 
Certain occupations and industries were integrated (e.g., in printing and publishing, textiles). Other industries, however, were formed entirely around male workers, for whom entrylevel occupations were often used as screening and training grounds for higher-level occupations to isolate the higher-level occupations from integration and ensure that selection to them was from a pool of male workers entire industries were segregated. ${ }^{46}$ These industries were organized in ways that differed radically from those in the female-intensive and mixed sectors, but it is not clear whether the differences were due to strength and skill requirements, the need for apprenticeships, higher costs of having division of labor, or the absence of piece-rate work. ${ }^{47}$ Because considerable strength was required in manufacturing work in the past, the male and female characteristic distributions may not have overlapped entirely and the male distribution may have had a longer right hand tail whereas the female distribution may have had a longer left hand tail. In terms of the predictions of the framework regarding where occupational segregation would be found, the evidence corroborates the notion that segregated occupations in manufacturing were found at the tails of the female earnings distribution.

both male and female workers. See Goldin (1990), p. 104.

${ }^{46}$ One observer commented on the integration of certain parts of the metal industry that " $[\mathrm{t}] \mathrm{he}$ displacement of the boy has one serious disadvantage. When boys worked at these tasks it was possible to pick out the clever and ready, who might be expected to become leading men and foremen. The girls do not furnish material for this purpose ... This at first unforeseen development will, in the view of many superintendents, check the tendency to replace boys with girls in many of the lighter occupations" (U.S. Senate 1910, vol. XI, pp. 15).

${ }^{47}$ Milkman (1987) demonstrates differences in the organization of work between the automobile and electrical industries around 1940. Greenwald (1980) documents hostility toward women workers during World War I. "Ordinarily, welding had been one stage in the apprenticeship of a machinist. During the war the process was separated for the fist time from this larger training program ... The employment of women as core makers in railroad foundries presented molders with a similar challenge ... Since the production of cores was a distinct stage in the training of apprentices, the molders' union strongly objected to the separation of core making from the entire program of training" (p. 117). It is not clear whether these apprenticeship stages were necessary to the entire production process or whether they were 
On average, female hourly earnings for occupations that were gender segregated were nearly identical to those that were integrated (weighted by the number of female employees), and among the few integrated occupations were some in printing and publishing, almost unique in early twentieth century manufacturing in employing relatively well-educated production workers. ${ }^{48}$ The segregated occupations, however, were found both at the very bottom and at the very top of the female earnings distribution. In clothing, the female-only trade of buttonhole makers "earn the highest wages among the female hand workers." Most firms, in addition, had female supervisors who were among the highest paid female shop floor workers. ${ }^{49}$

\section{Office Work in the Mid-Twentieth Century}

With the substitution of brains for brawn, the male and female characteristic distributions for office work should have had greater overlap than that for workers in manufacturing. Data on education levels for office workers reveal that although men had more years of college and advanced degrees, the bulk of men and women had a similar range of educational attainment.

Data on office workers for 1926 and for 1939 indicate that occupations were integrated at the lower end of the earnings or characteristic distribution but that a substantial fraction of women were employed in relatively high-paying (and high education) occupations that were almost entirely sex-segregated. ${ }^{50}$ With the exception of a few small occupations, the results conform to the predictions of the framework. A few segregated occupations existed at the very

maintained to prevent female workers from entering lower skilled positions.

${ }^{48}$ See U.S. Department of Labor (1905). Printing and publishing is also unique because its union enabled the integration of occupations in the twentieth century.

${ }^{49}$ On women's occupations and earnings in the clothing industry, see U.S. Senate (1910), vol. I, p. 458.

${ }^{50}$ Office worker earnings by occupation and sex are available for 1926 (National Industrial Conference Board 1926) and 1939 (U.S. Department of Labor 1942). Firm- and individual-level records have been 
low end, integration in the middle, and considerable segregation at the upper end. Unlike the manufacturing sector in which entire industries were segregated by sex and the majority of skilled jobs were de facto denied to women, many offices employed both men and women in the same lower-level occupations. Such integration opened up the possibility that men and women could be promoted to the same upper-level positions.

The response of many firms was to institute personnel policies that restricted upper-level occupations to one sex or the other. Firms reported that as personnel policy, rather than just "usual practice," they barred women from positions as teller, chief clerk, accountant, paymaster, collector, office manager, timekeeper, and auditor, among others. They also barred women from being hired as errand boy, messenger, order clerk, mail boy, claims clerk, and other low-paying jobs that were entry-level positions to male-only occupations. But they also barred men from becoming secretaries, stenographers, and machine operators of various types. ${ }^{51}$

Restrictions may have resolved potential conflict concerning the eventual placement of a woman or a man. "Wage discrimination" was the eventual result. Recall that differences in earnings by sex among manufacturing workers in 1890 were due primarily to differences in attributes. But among clerical workers in 1940, only about 39 percent of the difference in earnings by sex can be explained in a similar manner. ${ }^{52}$ In the very loose labor market of the 1930's few new positions in the upper end of the distribution were created and few old ones

sampled from the original surveys in the National Archives. See Goldin (1986, 1990, 2002).

${ }^{51}$ The occupations are from original, firm-level schedules from the Department of Labor, Women's Bureau (1942) located in the National Archives, Record Group 86.

${ }^{52}$ Using the male weights discrimination explains 55 percent, and using the female weights it explains 67 percent; the average is 61 percent. Therefore differences in attributes explain 39 percent of the difference in (log) earnings. See Goldin (1986) table 3 or Goldin (1990), chapter 4. 
became feminized. Further, the existence of barriers to entry in the occupations just mentioned served to reinforce the status quo.

To explore the relationship between earnings and the fraction female in the occupation, individual-level data from a 1940 Women's Bureau survey on office workers are used to estimate the earnings functions in Table 1. The dependent variable is (log) full-time annual earnings, and total office experience, its square, tenure with the firm, marital status, and years of education are the independent variables. The sex ratio of the occupation (the sample includes 75 separately enumerated occupations) and its square are also added.

Earnings initially decrease with the sex ratio (female/total employees) of the occupation and then rise, reaching a minimum at 56 percent female (see coefficients in column 1). The turning point is almost identical if the controls for characteristics (e.g., education, job experience) are excluded and if higher order terms for fraction female are introduced.

Because the average woman was in an occupation that was 71 percent female, female earnings generally increased with the sex ratio of the occupation. ${ }^{53}$ Note that the relationship between the sex ratio and earnings is similar for the male sample, but the turning point occurs at 55 percent female and the average male was in an occupation that was 27 percent female. Therefore male earnings, on average, decreased with the fraction female in the occupation. It should also be mentioned a similar relationship is found if education rather than earnings is the

\footnotetext{
53 This finding might appear to contradict that found in some studies using more recent data, such as Sorensen (1987), although see Filer (1989), who uses 430 occupations and a large group of occupational controls, O'Neill (1983) who estimates a nonlinear relationship, and Macpherson and Hirsch (1995) who use longitudinal data to account for unmeasured individual characteristics and preferences. According to Macpherson and Hirsch, "the remaining effects of gender composition on male or female wages appear rather small" (p. 460).
} 
dependent variable. The more segregated occupations in office work in 1940, therefore, contained women with higher levels of education. ${ }^{54}$

World War II and the tight labor market of the 1950's were effective in altering gender distinctions in some occupations but far fewer than might have been expected. One of the most radical shifts was in banks. During the war women were employed as bank tellers, practically a male-only clerical occupation in 1926 , but after the war bank tellers were rarely men. ${ }^{55}$

Interestingly, the relative earnings of bank tellers had declined long before the feminization of the occupation. Thus any real deskilling of the occupation preceded the entry of women and male bank tellers, it appears, managed to hold on to their occupation long after $\Omega=1$.

D. Occupational Segregation Post-1950's

"Wage discrimination" evident in 1940 was strongest for those at the upper end of the education scale and for those with substantial work experience. ${ }^{56}$ Occupations reserved for college-educated women were few in number and the list closed to them was extensive. A comprehensive personnel survey taken in the mid-1950's revealed that firms were not accommodating the rapidly increasing group of college-educated women. ${ }^{57}$ In terms of Figure 3 , female-only or integrated occupations in $B B^{\prime}$ did not expand and women were crowded into

\footnotetext{
${ }^{54}$ Among female employees having less than 12 years of schooling, the mean fraction female by occupation was 0.67 , whereas the same for female employees having more than 11 years was 0.73 . 55 On bank tellers in the mid-twentieth century, see Strober and Arnold (1987).

${ }^{56}$ Goldin (1986, table 3) reports the coefficients for the male and female earnings equations. "Years of education" has a higher coefficient for females than males, but the college, vocational, and high school dummies are considerably larger for males. Education has a more continuous impact for women, while the effect for men is in steps, possibly allowing them to begin on a different occupational ladder.

${ }^{57}$ Goldin (1990) discusses Hussey/Palmer personnel surveys taken in 1956/7 of the major employers in Philadelphia. The 50 interviews reveal that college women, except teachers and nurses, did not have a place in these firms.
} 
occupations around $B$. It is not surprising, therefore, that when discontent with the labor market was voiced by women in the 1960's, the most discontent were the college educated.

Various empirical studies of discrimination in the 1970's and 1980's indicated that the labor market had finally responded and that wage discrimination was lower, not higher, among the more highly educated. ${ }^{58}$ The decrease in discrimination over the long run may have been due to the emergence of "credentialized" occupations that could not be polluted by the presence of women. But some of the decline from the 1960's to the 1980's may also have been due to antidiscrimination legislation and to an environment in which discrimination was less tolerated.

Despite the decrease in empirical measures of discrimination for the most educated, the relationship between earnings and occupational segregation appears similar to that presented above for the two earlier periods. O’Neill finds that female earnings decrease as one moves from no women in an occupation to 0.5 , but that female earnings rise as one moves from 0.5 to female-only occupations. ${ }^{59}$ Further, non-monotonicity is strongest for younger and more educated women suggesting, perhaps, that the lower degree of wage discrimination for these groups owes to the creation of female-only occupations rather than the integration of previously existing male-only occupations.

III. Summary and Implications

I have suggested that discrimination against women is motivated, in part, by the desire of men to protect their occupational status. When work took more brawn than brain, the attribute

\footnotetext{
${ }^{58}$ See Filer (1983) and Blau and Beller (1986).

${ }^{59}$ O’Neill (1983) uses National Longitudinal Survey data for 1978 and an extensive set of controls.
} 
distributions of men and women were rather far apart. "Men's work" was perceived as better than "women's work" and observing a woman doing a man's job signaled that the man's job had been downgraded, possibly because of a technological shock. In a static context the model predicts ranges of segregation and integration of occupations along the characteristic scale.

As machines substituted for strength, as brain replaced brawn and as educational attainment increased, the distributions of attributes narrowed by sex. The dynamic implications of the framework and the historical evidence are revealing. Important lags existed in the labor market, hampering its ability to devise jobs for new groups of workers. Some lags arose from the institutionalization of occupational barriers, as was the case for firms hiring office workers in the 1930's, and some came from worker expectations about which jobs were appropriate for male and female workers. Older industries remained highly segregated by sex, while newer industries took greater advantage of the newly available female labor supply.

The results of the model depend on the existence of asymmetric information. Women know their own characteristics, as do those who hire them, but others in the community do not. Any mechanism that increases information, such as the credentialization of occupations, will foster integration. Similarly, the visibility successful women today and in the past may help shatter old stereotypes and increase knowledge about the true distribution of female attributes. 


\section{References}

Abbott, Edith. 1907. "Employment of Women in Industries: Cigar-Making - Its History and Present Tendencies," Journal of Political Economy, 15 (January): 1-25.

Abbott, Edith. 1909. Women in Industry: A Study in American Economic History. New York: D. Appleton and Company.

Abbott, Edith, and S. P. Breckinridge. 1911. "Women in Industry: The Chicago Stockyards," Journal of Political Economy 19 (October): 632-54.

Aigner, Dennis J., and Glen G. Cain. 1977. "Statistical Theories of Discrimination in Labor Markets," Industrial Labor Relations Review 30 (January): 175-87.

Akerlof, George A., and Rachel E. Kranton. 2000. "Economics and Identity," Quarterly Journal of Economics 115 (August): 715-53.

Altonji, Joseph G., and Rebecca M. Blank. 1999. "Race and Gender in the Labor Market." In Orley C. Ashenfelter and David Card, eds., Handbook of Labor Economics Vol. 3c, chapter 48. Amsterdam: North Holland-Elsevier Press.

Arrow, Kenneth. 1973. "The Theory of Discrimination." In Orley Ashenfelter and Albert Rees, eds., Discrimination in Labor Markets. Princeton: Princeton University Press.

Becker, Gary. 1957. The Economics of Discrimination. Chicago: University of Chicago Press.

Bidwell, Percy Wells, and John I. Falconer. 1925. History of Agriculture in the Northern United States: 1620-1860. Washington, D.C.: Carnegie Institution.

Blau, Francine D. 1977. Equal Pay in the Office. Lexington, MA: Lexington Books.

Blau, Francine D., and Andrea H. Beller. 1988. "Trends in Earnings Differentials by Sex: 19711981," Industrial and Labor Relations Review 41 (July): 513-29.

Breckinridge, S. P. 1906. “Legislative Control of Women's Work,” Journal of Political Economy 14 (February): 107-109

Caplow, Theodore. 1954. The Sociology of Work. Minneapolis: University of Minnesota Press.

Coate, Stephen, and Glenn C. Loury. 1993 "Will Affirmative-Action Policies Eliminate Racial Stereotypes?" American Economic Review 83 (December): 1220-40.

Davies, Margery W. 1982. Women's Place is at the Typewriter: Office Work and Office Workers, 1870-1930. Philadelphia: Temple University Press. 
Douglas, Mary. 1966. Purity and Danger: An Analysis of Concepts of Pollution and Taboo. London: Routledge and Kegan Paul Ltd.

Filer, Randall. 1983. "Sexual Differences in Earnings: The Role of Individual Personalities and Tastes," Journal of Human Resources, 18 (Winter): 82-95.

Filer, Randall K. 1989. “Occupational Segregation, Compensating Differentials, and Comparable Worth.” In Robert T. Michael, Heidi Hartmann, and Brigid O'Farrell, eds., Pay Equity: Empirical Inquiries. Washington, D.C.: National Academy Press, pp. 153-70.

Garrison, Dee. 1979. Apostles of Culture: The Public Librarian and American Society, 18761920. New York: The Free Press.

Goldin, Claudia. 1986. "Monitoring Costs and Occupational Segregation by Sex: A Historical Analysis," Journal of Labor Economics (January): 1-27.

Goldin, Claudia. 1987. "The Gender Gap in Historical Perspective.” In Peter Kilby, ed., Quantity and Quiddity: Essays in Honor of Stanley Lebergott. Middletown, CT: Wesleyan University Press.

Goldin, Claudia. 1990. Understanding the Gender Gap: An Economic History of American Women. New York: Oxford University Press.

Goldin, Claudia. 2002. “The Rising (and then Declining) Significance of Gender.” NBER Working Paper no. 8915 (April).

Goldin, Claudia, and Kenneth Sokoloff. 1982. "Women, Children, and Industrialization in the Early Republic: Evidence from the Manufacturing Censuses." Journal of Economic History, 42 (December): 741-74.

Goldin, Claudia, and Kenneth Sokoloff. 1984. "The Relative Productivity Hypothesis of Industrialization: The American Case, 1820-1850," Quarterly Journal of Economics 99 (August): 461-88.

Greenwald, Maurine Weiner. 1980. Women, War, and Work: The Impact of World War I on Women Workers in the United States. Westport, CT: Greenwood Press.

Harris, Barbara J. 1978. Beyond Her Sphere: Women and the Professions in American History. Westport, CT: Greenwood Press, 1978.

Humphries, Jane. 1987. “ ‘... The Most Free From Objection ...’ The Sexual Division of Labor and Women's Work in Nineteenth-Century England," Journal of Economic History 47 (December): 929-49. 
Jacobs, Jerry. 1989. "Long-Term Trends in Occupational Segregation by Sex," American Journal of Sociology 95 (July): 160-73.

Jacobsen, Joyce. 1994. “Trends in Workforce Sex Segregation: 1960 to 1990," Social Science Quarterly 75 (March): 204-11.

Kanter, Rosabeth Moss. 1977. Men and Women of the Corporation. New York: Basic Books.

Lang, Kevin. 1986. "A Language Theory of Discrimination," Quarterly Journal of Economics 101 (May): 363-382.

Lundberg, Shelley J., and Richard Startz. 1983. "Private Discrimination and Social Intervention in Competitive Labor Markets," American Economic Review, 73 (June): 340-47.

Macpherson, David A., and Barry T. Hirsch. 1995. "Wages and Gender Composition: Why Do Women's Jobs Pay Less?” Journal of Labor Economics 13 (July): 426-71.

Milgrom, Paul and Sharon Oster. 1987. "Job Discrimination, Market Forces, and the Invisibility Hypothesis,” Quarterly Journal of Economics 102 (August): 453-476.

Milkman, Ruth. 1987. Gender at Work: The Dynamics of Job Segregation by Sex during World War II. Urbana, IL: University of Illinois Press.

Morello, Karen Berger. 1986. The Invisible Bar: The Woman Lawyer in America, 1638 to the Present. New York: Random House.

National Industrial Conference Board. 1926. Clerical Salaries in the United States, 1926. New York: National Industrial Conference Board.

O’Neill, June. 1983. "The Determinants and Wage Effects of Occupational Segregation," The Urban Institute, Washington, D.C. Unpublished paper. (March).

Phelps, Edmund S. 1972. "The Statistical Theory of Racism and Sexism," American Economic Review 62 (September): 659-61.

Reskin, Barbara F., and Patricia A. Roos. 1990. Job Queues, Gender Queues: Explaining Women's Inroads into Male Occupations. Philadelphia, PA: Temple University Press.

Sorensen, Elaine. 1990. "The Crowding Hypothesis and Comparable Worth Issue," Journal of Human Resources 25 (Winter): 55-89.

Strober, Myra H., and Carolyn L. Arnold. 1987. "The Dynamics of Occupational Segregation among Bank Tellers." In Clair Brown and Joseph A. Pechman, eds., Gender in the 
Workplace. Washington, D.C.: The Brookings Institution, pp. 107-48.

U.S. Census Office. 1895. Report on Manufacturing Industries in the United States, Eleventh Census: 1890. Part I. Totals for States and Industries. Washington, D.C.: G.P.O.

U.S. Department of Labor. 1905. Nineteenth Annual Report of the Commissioner of Labor, 1904. Wages and Hours of Labor. Washington, D.C.: G.P.O.

U.S. Department of Labor, Women's Bureau. 1920. The New Position of Women in American Industry. Bulletin of the Women's Bureau, No. 12. Washington, D.C.: G.P.O.

U.S. Department of Labor, Women's Bureau. 1942. Office Work in Houston, Los Angeles, Kansas City, Richmond, and Philadelphia. Bulletin of the Women's Bureau, Nos. 188-1, 2, 3, 4, 5. Washington, D.C.: G.P.O.

U. S. Senate. 1910. Report on Condition of Woman and Child Wage-Earners in the United States in 19 Volumes. Washington, D.C.: G.P.O. 
Figure 1

The Model with Identical Distributions of $C$ for Men and Women

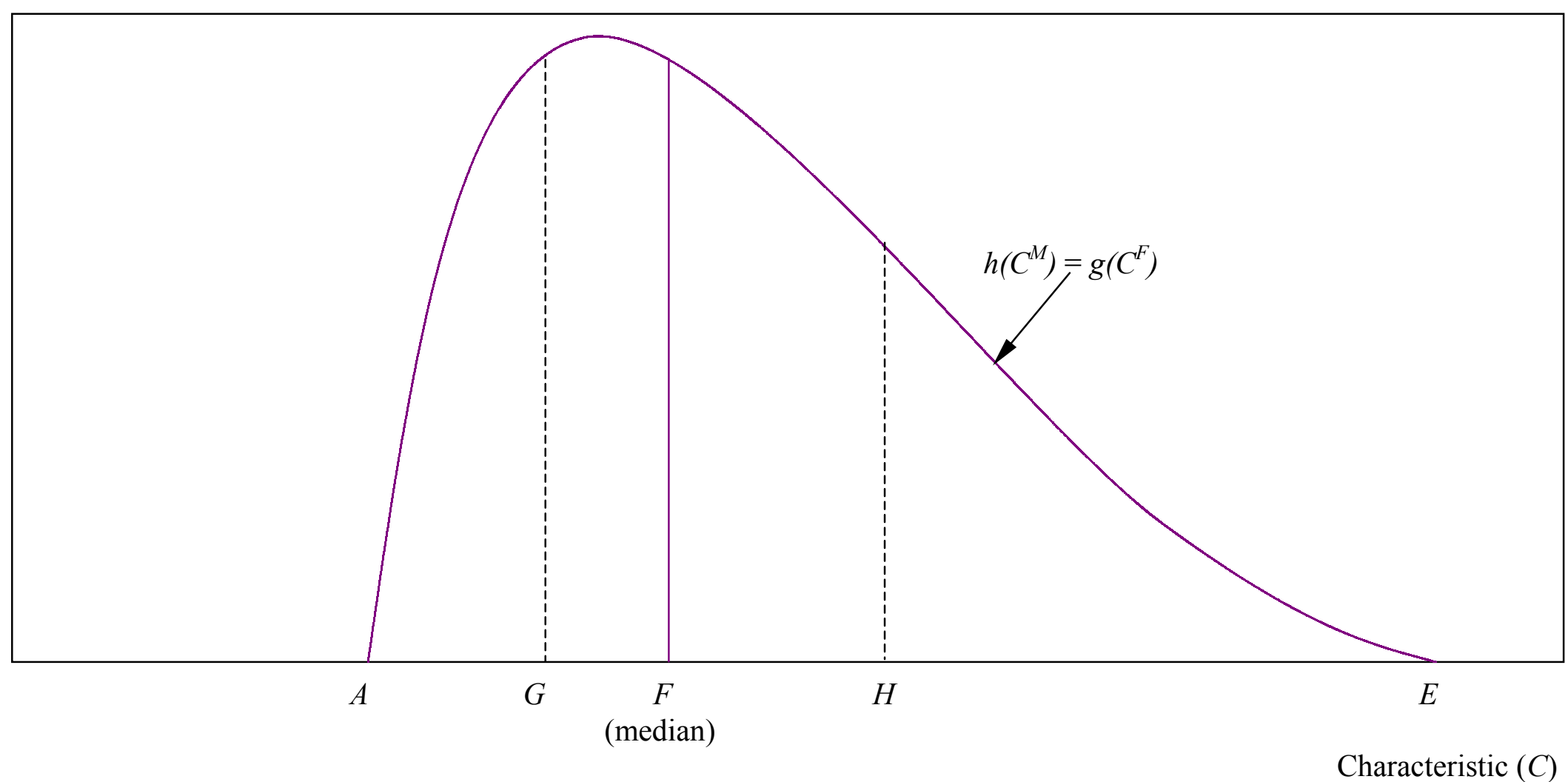

Pollution Theory 37 
Figure 2

The Model with Different Distributions of $C$ for Men and Women

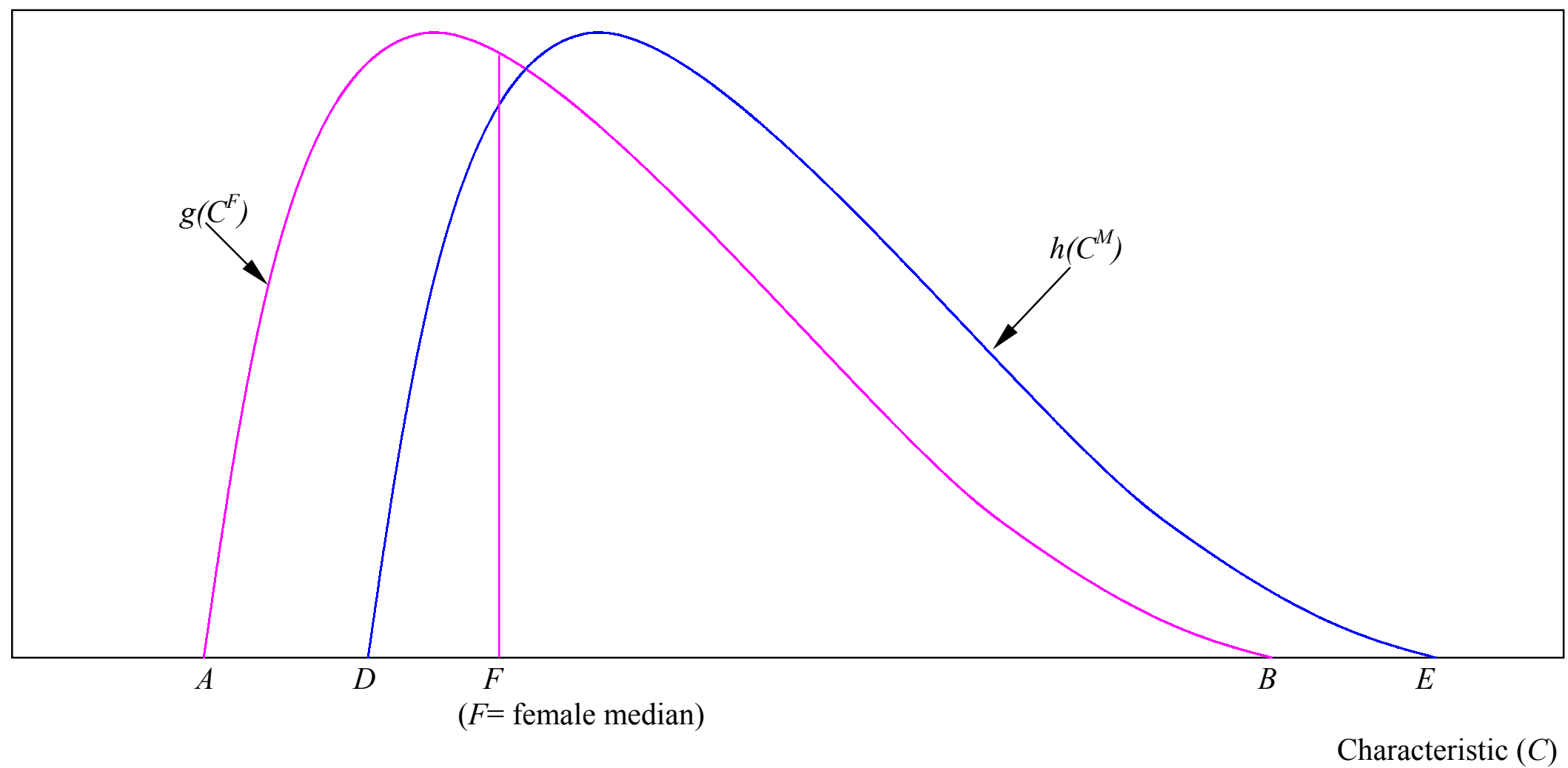

Pollution Theory 38 
Figure 3

The Model with Different Distributions of $C$ for Men and Women and a Change in the $C$ Distribution for Women

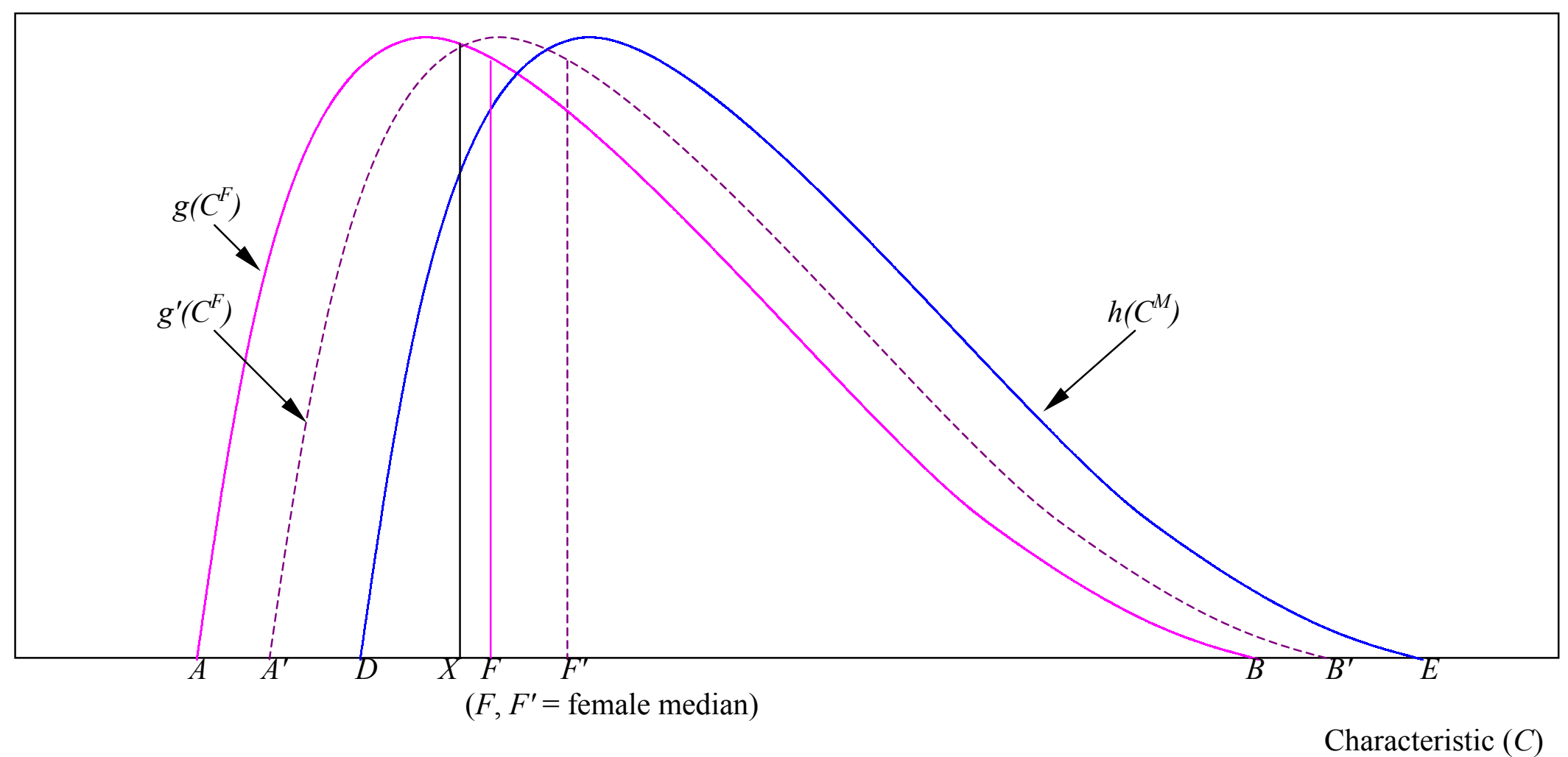

Pollution Theory 39 
Table 1

Earnings Functions for Male and Female Office Workers, 1940

\begin{tabular}{|c|c|c|c|c|}
\hline & \multicolumn{2}{|c|}{$\begin{array}{c}(1) \\
\text { Females }\end{array}$} & \multicolumn{2}{|c|}{$\begin{array}{l}(2) \\
\text { Males }\end{array}$} \\
\hline & $\begin{array}{l}\text { Coefficient } \\
\text { (s.e.) }\end{array}$ & Means & $\begin{array}{c}\text { Coefficient } \\
\text { (s.e.) }\end{array}$ & Means \\
\hline $\begin{array}{l}\text { Dependent Variable: } \\
\text { Log of full-time yearly salary }\end{array}$ & & 6.95 & & 7.34 \\
\hline Total office experience & $\begin{array}{c}0.0313 \\
(0.00215)\end{array}$ & 10.839 & $\begin{array}{c}0.0474 \\
(0.00230)\end{array}$ & 13.04 \\
\hline Total office experience squared $\mathrm{H} 10^{-2}$ & $\begin{array}{c}-0.0559 \\
(0.00598)\end{array}$ & & $\begin{array}{c}-0.0747 \\
(0.00479)\end{array}$ & \\
\hline Experience with current firm & $\begin{array}{c}0.0146 \\
(0.00151)\end{array}$ & 7.61 & $\begin{array}{c}0.0127 \\
(0.00150)\end{array}$ & 10.5 \\
\hline Years schooling & $\begin{array}{c}0.0373 \\
(0.00344)\end{array}$ & 11.5 & $\begin{array}{c}0.0475 \\
(0.00306)\end{array}$ & 11.8 \\
\hline Married & $\begin{array}{l}-0.0101 \\
(0.0145)\end{array}$ & 0.197 & $\begin{array}{c}0.136 \\
(0.0164)\end{array}$ & 0.488 \\
\hline Sex ratio of current occupation & $\begin{array}{l}-0.796 \\
(0.131)\end{array}$ & 0.709 & $\begin{array}{l}-0.743 \\
(0.0859)\end{array}$ & 0.267 \\
\hline Sex ratio squared & $\begin{array}{c}0.710 \\
(0.105)\end{array}$ & & $\begin{array}{c}0.673 \\
(0.105)\end{array}$ & \\
\hline Constant & $\begin{array}{c}6.339 \\
(0.0595)\end{array}$ & & $\begin{array}{c}6.262 \\
(0.0465)\end{array}$ & \\
\hline Number of observations & 1,420 & & 1,528 & \\
\hline$R^{2}$ & 0.496 & & 0.642 & \\
\hline
\end{tabular}

Source: National Archives, Record Group 86, Boxes 472-86, original schedules for U.S. Department of Labor, Women's Bureau (1942) for Philadelphia. See Goldin $(1986,1990)$, which uses a somewhat smaller sample of records; Goldin (2002) uses the expanded sample that is used here as well.

Notes: Standard errors are in parentheses. "Total office experience" is the sum of all work experience in offices. "Sex ratio" is the fraction female in each of the 75 occupations in the sample. 